\title{
RELASI AGAMA DAN SAINS \\ DALAM PANDANGAN MEHDI GOLSHANI
}

\section{Syarif Hidayatullah}

Fakultas Filsafat, Universitas Gadjah Mada, Yogyakarta

Email: syarifhidayatullah@ugm.ac.id

\section{Abstrak}

Penelitian ini bertujuan untuk mengetahui pemikiran Mehdi Golshani tentang relasi agama dan sains dan relevansinya dalam pengembangan keilmuan agama dan sains. Hasil penelitian ini adalah: pertama, dalam memahami relasi agama dan sains, Golshani menggunakan istilah ilmu sakral (sacred sciences) dan ilmu sekuler (secular sciences). Gagasan tentang sains sakral dikembangkan Golshani menjadi apa yang ia sebut sebagai "sains Islam". Golshani mendefinisikan "sains Islam" sebagai jenis sains yang di dalamnya pengetahuan tentang dunia fisik terkandung dalam pandangan dunia Islam, yang nilainilainya dirumuskan al-Quran. Golshani menekankan pentingnya kesadaran terhadap epistemologi Qur'ani ini ditumbuh-kembangkan kembali oleh umat Islam. Kedua, untuk mewujudkan harapan-harapan ideal dalam relasi sains dan agama serta kemanfaatannya bagi kemaslahatan umat manusia dan keselarasan alam semesta tersebut, maka pemikiran Golshani beserta tawaran implementatifnya, terutama dengan upaya-upaya pengembangan bidang-bidang ilmu kealaman di kalangan umat Islam, merupakan sesuatu yang sangat penting dan patut dipertimbangkan.

Kata Kunci: Ilmu Sakral, Sains Islam, Epistemologi Qur'ani

\section{Abstract}

This research aims to know Mehdi Golshani's thought on relationship between science and religion, and its relevance to development of science and religion scientifically. Results of this research are: first, Golshani uses two terms which are "the sacred sciences" and "the secular sciences" to understand the relationship between science and religion. Then, his idea of "the sacred sciences" is developed to become "Islamic Science". He defines that the "Islamic Science" is a kind of science that has a weltanschauung which bases on the Quran values. Here, Golshani stresses on an importance to develop the Quran epistemology in Moslems society. Second, to create ideal expectations in the relationship between science and religion and its benefits for humankind and harmony in the universe, Mehdi Golshani's thoughts and implementable offers, especially for 
developing natural sciences in the Moslems society, are an urgent and considerable thing.

Keywords: "the sacred sciences", the "Islamic Science", the Quran epistemology

\section{PENDAHULUAN}

Sejak dasawarsa 1970-an hingga sekitar awal 1990-an, menurut Zainal Abidin Bagir (2002: 144), telah berkembang sebuah dinamika baru di dunia Islam, khususnya dalam persoalan relasi antara Islam dan ilmu pengetahuan, dengan munculnya Islamic science (ilmu pengetahuan Islam) atau Islamisasi ilmu (Islamization of knowledge). Beberapa nama inteletual Muslim bermunculan berusaha memaknai istilah tersebut dengan cara yang beragam, bahkan tidak jarang saling bersilang pendapat.

Mehdi Golshani, misalnya, adalah salah satu nama yang tidak boleh diabaikan begitu saja ketika membahas diskursus tentang relasi antara agama dan sains, khususnya dalam tradisi Islam. Sebut saja salah satu alasannya adalah, Golshani dinilai, setidaknya oleh Zainal Abidin Bagir, memiliki cara yang "konstruktif" dan "tak superfisial" dalam membahas isu-isu agama dan sains (2004: xiv). Selain itu, kredibilitas dan otoritas Golshani tak diragukan sebagai seorang fisikawan yang aktif dan produktif melakukan riset yang terfokus pada beberapa masalah dasar dalam kosmologi dan mekanika kuantum. Golshani juga tertarik untuk mengkaji filsafat sains dan, bahkan, menginisiasi pendirian jurusan filsafat sains di universitas, serta bersedia menjadi direkturnya (2004: xiii).

Dengan latar belakang seperti dikemukakan di atas, maka rumusan masalah yang akan diteliti lebih jauh dalam penelitian ini adalah: pertama, bagaimana pemikiran Mehdi Golshani tentang relasi agama dan sains?, dan, kedua, bagaimana relevansi pemikiran Mehdi Golshani dalam pengembangan keilmuan agama dan sains?. Dengan demikian, penelitian ini bertujuan untuk mengetahui dan memahami: pertama, pemikiran Mehdi Golshani tentang relasi agama dan sains, dan, kedua, relevansi pemikiran Mehdi Golshani dalam pengembangan keilmuan agama dan sains. 


\section{MERINTIS JALAN RELASI AGAMA DAN SAINS}

Menurut Zaenal Abidin Bagir (2006: 3), diskursus tentang agama dan sains menemukan bentuk baru yang subur dan sistemik dalam sekitar empat dasawarsa terakhir. Maksud sistemik di sini adalah bahwa, seperti halnya suatu bidang kajian, sudah terdapat perdebatan tentang pendekatan, metodologi dan ruang lingkupnya, tumbuhnya forum-forum akademis yang mewadahi perdebatan tersebut baik dalam bentuk seminar, konferensi, maupun penerbitan jurnal yang khas, dan bahkan di beberapa perguruan tinggi mulai dirancang dan diimplementasikan dalam bentuk matakuliah-matakuliah terkait, serta semakin beredarnya buku-buku teks dan referensi yang mengkaji persoalan seputar agama dan sains. Salah satunya adalah buku Sains dan Problem Ketuhanan yang ditulis oleh Greg Soetomo pada 1995, yang semula merupakan karya skripsi di STF Driyarkara, Jakarta. Secara garis besar, ada tiga hal pokok yang dikemukakan dalam buku tersebut, yaitu: pertama, berkaitan dengan perkembangan sains yang mampu memberikan bukti empiris dan matematis untuk menyempitkan bahkan menghilangkan relijiusitas yang seringkali diikuti dengan klaim filosofis yang sebenarnya bukan wewenang sains. Kedua, tentang adanya kurun waktu di mana berlangsung kemajuan sains yang justru menerangi dimensi relijiusitas, meskipun bukan diartikan bahwa persoalan iman, wahyu, keberadaan Allah dan dimensi relijiusitas lainnya telah dianggap selesai. Ketiga, adalah bahwa kemajuan sains ternyata juga memberikan "pekerjaan rumah" yang tidak sedikit dalam rupa problem-problem filosofis dimensi relijius, iman, dan wahyu bagi filsafat Ketuhanan (Soetomo, 1995: 128).

Namun demikian, pertemuan filsafat, teologi dan sains, menurut Louis Leahy, adalah sesuatu yang esensial agar Iman tampak sekaligus pantas dipercayai dan relevan bagi tiap generasi yang hidup dalam suatu visi tertentu tentang alam semesta (2006: 19). Oleh sebab itu, berdasarkan kajiannya seputar perdebatan agama dan sains di era modern, Leahy terobsesi untuk mendorong terjadinya kolaborasi antardisiplin, untuk mengurangi intensitas perseteruan agama dan sains. Salah satunya adalah berharap pada kontribusi khas para ilmuwan 
yang selalu berpijak pada objektivitas data-data keilmuan yang dikumpulkan, kekokohan analisis, semangat tanpa pamrih dalam mengabdi kebenaran, dan sikap yang mementingkan nilai moral, yang merupakan hal yang penting sekali, bahkan mutlak, demi memperkuat, memperkaya, dan melindungi sektor lain kehidupan intelektual, rohani, dan praktis umat manusia (2006:32).

Dalam konteks seperti inilah Mehdi Golshani, tokoh yang menjadi obyek kajian ini, telah melakukan kontribusi nyata dengan-salah satunya--menyusun sebuah buku bertajuk The Holy Quran and the Science of Nature pada 1986, yang edisi Indonesianya diterbitkan oleh Penerbit Mizan pada 1988 dengan judul Filsafat Sains Menurut al-Quran.

\section{MENDEFINISIKAN SAINS DAN AGAMA}

Istilah "sains" atau "ilmu, dalam pengertian lengkap dan komprehensif, adalah serangkaian kegiatan manusia dengan pikirannya dan menggunakan berbagai tata cara sehingga menghasilkan sekumpulan pengetahuan yang teratur mengenai gejala-gejala alami, kemasyarakatan, dan perorangan untuk tujuan meraih kebenaran, pemahaman, penjelasan, atau penerapan. Kata "sains" berasal Latin, scientia ("science", bahasa Inggris), yang berarti pengetahuan, sedangkan pada kelanjutannya berasal dari bentuk kata kerja scire, yang berarti mempelajari, mengetahui (Gie, 2003: 19).

Dalam kajian Gie, istilah "science" dalam literatur Barat, mengandung lima cakupan, yang merupakan pertumbuhan kesejarahan dari pemikiran manusia yang saling melengkapi. Bahkan, bisa dikatakan, dari cakupan satu ke cakupan berikutnya terjadi penegasan makna sehingga menjadi pengertian ilmu dalam artian dewasa ini. Cakupan ilmu yang pertama dan tertua adalah sesuai dengan asal usul dari kata "science" yang mengacu pada "pengetahuan semata-mata mengenai apa saja". Dalam kelaziman Bahasa Inggris kuno hingga abad ke-17, science memang diartikan apa saja yang harus dipelajari oleh seseorang, misalnya menjahit dan menunggang kuda. Cakupan kedua, bahwa sesudah abad ke-17 dan memasuki abad berikutnya, pengertian science mengalami penghalusan dan mengacu pada pengetahuan yang 
teratur. Cakupan ketiga, science sebagai ilmu kealaman, yang hingga sekarang masih dipertahankan oleh sebagian pakar. Ilmu pengetahuan alami dalam perkembangannya terpecah menjadi cabang-cabang ilmu, seperti Ilmu Alam, Ilmu Hayat, dan Ilmu Kimia yang bersifat lebih khusus. Masing-masing cabang ilmu yang khusus ini merupakan cakupan keempat. Terakhir, cakupan kelima, pengertian ilmu seumumnya; yang muncul akibat pembahasan lebih lanjut, misalnya, tentang peranan ilmu, rakitan ilmu, atau sejarah ilmu, yang menyebabkan orang harus berbicara mengenai segenap ilmu sebagai suatu kebulatan atau ilmu seumumnya dan bukan pada masing-masing cabang ilmu yang bersifat khusus, seperti sebelumnya (2003: 20).

Sedangkan agama, menurut Sir Muhammad Iqbal (2016: 239), dipilah ke dalam tiga dimensi: keimanan (faith), pemikiran (thought), dan petualangan diri (discovery). Agama, menurut Burhanuddin Daya (1993), merupakan kesempurnaan eksistensi manusia, sumber vitalitas yang mewujudkan perubahan dunia dan melestarikan kehidupan manusia. Kualitas suatu perubahan ditentukan oleh kualitas agama yang menjadi dasarnya. Agama juga salah satu sumber nilai, memiliki peran, arti dan bahkan sumbangan yang sangat besar dan paling tinggi harganya bagi setiap jenjang kehidupan manusia. Semua kebudayaan besar dan bersejarah telah berakar dalam agama-agama besar. Max Muller mendefinisikan agama sebagai keadaan mental atau kondisi pikiran yang bebas dari nalar dan pertimbangan sehingga menjadikan manusia mampu memahami Yang Maha Tak Terbatas melalui berbagai nama dan perwujudan (Menzies, 2014:11).

\section{DISKURSUS RELASI AGAMA DAN SAINS DALAM KONTEKS ISLAM}

Ketika agama dan sains mengalami ketegangan, menurut Hidayat (2014: 97), dibutuhkan berbagai cara untuk menjembatani keduanya agar dapat saling mengisi dan tidak saling meniadakan. Satu hal yang patut diapresiasi adalah bahwa saat ini para agamawan (ilmuwan teolog) terutama dari kalangan Islam maupun Kristen telah memiliki kecenderungan positif untuk terjun langsung dalam dunia sains yang 
sangat luas ini. Kalau selama ini kalangan agamawan banyak yang hanya berada di pinggiran sebagai penonton yang sering kecewa atau dikecewakan oleh arus perkembangan sains, maka "agama" paling tidak telah memiliki wakil-wakil tangguhnya, masuk ke gelanggang dan bermain dengan aturan sains. Tokoh-tokoh seperti Ian Barbour, John F. Haught, Keith Ward, Peacocke, Mehdi Golshani, Huston Smith, Fritjof Capra, dan tokoh-tokoh lainnya merupakan sebagian dari pelaku wacana baru dalam menghubungkan sains dan agama.

Upaya-upaya mereka mulai bisa dirasakan hasilnya dalam perkembangan yang terkini. Saat ini, orang cenderung tidak serta merta mempertentangkan seluruh capaian sains dengan keyakinan agama yang dimilikinya. Termasuk ketika mendiskusikan kembali isu-isu sensitif dan laten yang menjadi problem awal relasi agama dan sains sekaligus yang dahulu telah memantik keregangan dan, bahkan, konflik antara keduanya. Misalnya, ketika menilik kembali persoalan seputar pertentangan yang terjadi antara teori evolusi dan agama, sebagian kalangan sudah menyadari bahwa seharusnya tidak perlu dikonfrontasikan karena keduanya dapat saling mengisi dan mendukung. Di sini pentingnya upaya melakukan integrasi antara akal yang melahirkan sains dengan pandangan teologis yang lebih terbuka dalam memandang dalil-dalil kitab suci yang berbicara tentang fenomena alam. Dengan pemahaman yang holistik tentang cara alam dan cara Tuhan bekerja, menurut Hidayat, maka kehadiran agama atau Tuhan dalam sains seharusnya tidak perlu diingkari, apalagi ditakuti. Hidayat merujuk keyakinan ini pada apa yang dikatakan Keith Ward dalam bukunya God, Chance and Necessity, bahw "God is beginning to argue back", merupakan tanda bahwa hubungan antara agama dan sains sesungguhnya dapat didekatkan dengan cara-cara yang lebih konstruktif dan seimbang jika keduanya masih sepakat untuk menemukan hakikat eksistensi dan problem jagad raya dalam sebuah tanggung jawab yang sama. Tanpa mengabaikan persoalan internal yang dihadapi baik oleh sains maupun agama, keduanya masih memiliki tanggung jawab kolektif yang patut dicarikan penyelesaiannya secara bijak dan akurat. Dicontohkan Hidayat, persoalan yang dihadapi seperti bencana yang terjadi pada masa kini dan mendatang: kemiskinan 
penduduk, perubahan iklim, erosi dan kekeringan, penebangan hutan, limbah, ketimpangan kekayaan, kriminalitas, degradasi moral, dan masalah-masalah lainnya menuntut jawaban dan solusi yang tepat dalam rangka mengejawantahkan peran sains dan agama sebagai pro kelestarian alam dan kemanusiaan. Bumi dan seisinya masih membutuhkan tangan-tangan sains dan agama guna memberikan rasa aman bagi semesta sehingga kesinambungan dan keselarasan dapat terjalin dan tertata, sampai semua akhirnya menyadari bahwa alam semesta dan seisinya adalah Hadiah Terindah dari Sang Pencipta. (2014: 98).

Kesadaran untuk tidak mempertentangkan sains dan agama, merupakan hal yang tak bisa diabaikan. Dalam tradisi Muslim, diskursus tentang relasi sains dan agama juga mengalami dinamika yang menggembirakan dan menyakinkan. Kajian yang dilakukan Mehdi Golshani, intelektual asal Teheran, Iran, dan Arqom Kuswanjono, doktor ilmu filsafat Universitas Gadjah Mada, adalah dua contoh yang patut diapresiasi dalam upaya memperkuat wacana tentang relasi sains dan agama. Dalam konteks ini Golshani mengajukan gagasan perlunya penafsiran sains secara Islam melalui apa yang ia sebut sebagai "Sains Islam". Buku Melacak Jejak Tuhan Dalam Sains: Tafsir Islami Atas Sains, Golshani mengatakan bahwa gagasan tentang sains Islam telah beredar sepanjang tiga puluh tahun terakhir. Ia mendefinisikan sains Islam sebagai jenis sains yang di dalamnya pengetahuan tentang dunia fisik terkandung dalam pandangan Islam (2004: 22; lihat juga Hidayatullah, 2015: 33 ). Sementara itu Kuwanjono melalui kajiannya berusaha mengungkap gagasan sains Islam dengan memilih studi kasus pandangan salah satu tokoh Islam, yaitu Mullla Sadra, dalam mendiskusikan wacana integrasi sains dan agama. Di sini Kuswanjono menyimpulkan bahwa Sadra secara cerdas dan jernih menempatkan ilmu dan agama pada posisi yang sangat harmonis, sehingga cukup memberikan frame yang jelas bagi perkembangan pemikiran Islam pada umumnya. Frame yang dirancang oleh pemikir Islam kelahiran Persia ini menjadi gambaran kontras dari perkembangan pemikiran Barat, yang cenderung menempatkan sains dan agama secara konfrontatif, bahkan, konflik. Apa yang dialami oleh Galileo Galilei, seorang saintis yang sezaman dengan Sadra, telah mengguncang dan mengoyak langit 
di Barat dengan penguatan teori heliosentrisme; sebuah teori kosmologis yang bertentangan dengan teori geosentrisme yang telah sekian abad menjadi kiblat keyakinan arus utama para saintis di eranya dan dibakukan melalui dogma gereja. Perkembangan baru ini pada akhirnya memicu relasi konflik berkepanjangan antara gereja dan para saintis, atau tepatnya agama dan sains (2010: 5-7).

Nama lain yang patut perbincangkan adalah M. Fethullah Gulen, seorang inteletual Muslim asal Turki, yang memandang ilmu pengetahuan dan iman tidak hanya bersesuaian (compatible) tetapi saling melengkapi. Karenanya, ia mendorong penelitian ilmiah dan pengembangan teknologi demi kebaikan umat manusia (Billa, 2011: 292). Fokus utama Gülen dalam hal ini adalah teologi, bahwa ia tertarik untuk membela posisi teologi Islam terhadap ilmu pengetahuan yang selama ini, disimpulkan Gülen, memainkan peran subordinatif. Agama dan sains, bagi Gülen, tidak bisa dianggap sama dalam Islam (Billa, 2011: 296). Gülen berupaya membangun kerangka metafisis untuk mendukung sudut pandang ilmiah Islam tentang kebenaran, yang notabenenya berlawanan dengan klaim materialisme. Dalam catatan Gülen, umat Islam sampai saat ini masih belum mengembangkan konsep ilmu dalam makna sebenarnya; berdasar pada nilai-nilai Islam dan diformulasi terutama dari al-Qur'ân dan praktik Nabi SAW. Gülen tegaskan bahwa asumsi pemisahan wahyu-akal yang selama ini dipahami, sebenarnya merupakan asumsi keliru, justru pertentangan yang seharusnya ada adalah antara pandangan sekuler dan religius. Sudut pandang sekuler pun, bagi Gülen, sebenarnya dapat diintegrasikan ke dalam pandangan dunia Islam, dengan prasyarat bersedia mengakui kegagalannya mengurai fakta-fakta penting tentang alam semesta, termasuk sifat pra-eksistensi, akhirat, dan alam supra-duniawi. Pandangan dunia materialis pun dapat dibenarkan dan diperkuat, jika dimasukkan dalam kerangka yang lebih besar mecakup karakteristik metafisik alam semesta, sebagaimana cara pandang Islam (Billa, 2011: 301302).

Gülen menegaskan bahwa teologinya tidak berusaha untuk mengakomodasi atau alih-alih minta maaf kepada konsep-konsep ilmiah modern, melainkan mempromosikan pandangan dunia Islam 
yang benar. Islam yang benar menurutnya harus mampu menyeimbangkan fungsi akal dan wahyu, mistisisme dan ortodoksi, aktivitas di dunia dan penghargaan di akhirat, dan antara doktrin dan praktik. Jika gagasan ini dipahami dalam kerangka Islam yang benar, maka takkan muncul perdebatan yang tak kunjung selesai seputar akal dan wahyu, atau ilmu pengetahuan dan Islam. Sebaliknya, ilmu pengetahuan modern dan Islam bisa saling melengkapi. Temuan sains dapat memperdalam pemahaman tentang Al-Qur'ân dan hukum-hukum Allah tentang alam semesta, yang memungkinkan umat Islam menata hidup mereka melalui interpretasi yang lebih tepat dan informasi syariah yang lebih akurat. Pandangan dunia Al-Qur'ân, pada sisi lain, mampu memperkaya ilmu pengetahuan untuk memahami karakter alam semesta sesungguhnya, di saat ilmu untuk memahami karakter alam semesta sesungguhnya, di saat ilmu pengetahuan tidak mampu mengeksplorasi persoalan-persoalan metafisika terkait sifat mukjizat, misteri penciptaan, pra-keabadian, alasan ada dan keber-ada-an, hanya wahyu yang dapat digunakan sebagai pedoman. Sebaliknya, beberapa ayat Al-Qur'ân dan ajaran Islam pun memerlukan pengetahuan dari fenomena alam dan konstanta universal. Pengetahuan ilmiah memungkinkan umat Islam untuk memiliki pemahaman lebih lengkapluas dan praktis-realistis mengenai pesan-pesan Al-Qur'ân dan teksteks suci-otoritatif lain (Billa, 2011:303).

Menurut Hidayat, dari dunia Islam untuk beberapa lama sempat menguat gagasan Islamisasi sains ataupun sains Islam, dengan pemukanya seperti Seyyed Hossein Nasr - yang mengkritik keras modernisme sebagai akibat perkembangan sains modern - dan Ziauddin Sardar. Namun gagasan mereka banyak dikritik bahkan dari kalangan muslim sendiri karena ide mereka dianggap tidak realitistik karena harus membongkar sistem sains yang sudah ada dan menggantinya dengan sistem yang sama sekali baru. Selain akan bermakna sains Islam akan menjadi eksklusif dan kehilangan spirit universalitasnya. Alih-alih merumuskan suatu sistem sains yang baru, fisikawan seperti Abdus Salam (Peraih Nobel Fisika 1979) justru lebih menganjurkan agar kaum Muslim berikhtiar mengejar ketertinggalan mereka dalam bidang sains dari sejawatnya di Barat. 


\section{MEMBACA PEMIKIRAN MEHDI GOLSHANI}

Mehdi Golshani adalah tokoh kelahiran Isfahan, Iran pada 1939. Setelah menyelesaikan pendidikan dasarnya di kota kelahirannya, Isfahan, yang merupakan pusat ilmu pengetahuan sejak zaman kejayaan Islam, Golshani melanjutkan ke jenjang pendidikan tinggi di Universitas Teheran. Selepas memperoleh gelar Bachelor of Science (B.S.) bidang fisika pada 1959, Golshani melanjutkan minat studinya bidang fisika di Universitas California, Berkeley, Amerika Serikat, yang kemudian ia raih gelar Ph.D pada 1969. Golshani selanjutya kembali ke negerinya, Iran, dan berkarir menjadi dosen di Universitas Teknologi Syarif, Teheran. Karenanya kepakarannya di bidang fisika, karir Golshani melejit dengan dipercaya menjadi ketua departemen fisika selama dua periode, pada 1973-1975 dan 1987-1989. Karirnya berlanjut dengan menjabat posisi wakil rektor di universitas ini. Dengan berbagai aktivitas dan karyanya di bidang pengajaran, penelitian dan penulisan karya ilmiah di sejumlah buku, seminar, dan jurnal internasional, akhirnya Golshani dinobatkan sebagai guru besar bidang fisika pada 1991 (Syamsuddin, 2012: 123-5).

Golshani adalah saintis Muslim yang termasuk generasi paling baru intelektual Muslim yang begitu tertarik dengan wacana relasi agama (baca: Islam) dengan sains modern. Pandangannya relatif jauh lebih akomodatif terhadap sains modern, jika dibanding dengan para pendahulu, seperti Ziaudin Sardar dan Syed Hussen Nasr. Kendati sama kritisnya dengan Nasr dalam menelisik sains modern, namun Golshani lebih memahami tugasnya dengan memberikan penafsiran Islami atas sains modern dan tidak begitu berhasrat untuk membangun suatu "sains Islami" yang samasekali jauh berbeda dengan sains modern yang sekuler. Golshani menemukan momentum karena belakangan memang kajian atas sejarah sains dalam peradaban Islam tidak lagi melulu diwarnai dengan aroma apologetik dan legitimitatif, namun dilakukan dengan jauh lebih akademik dan ketat sehingga memberikan gambaran yang lebih baik mengenai karakter sains tersebut dan menghilangkan, setidaknya meminimalisir, aroma idealisasi yang sangat kental pada kajian-kajian terdahulu (Bagir, 2006: 9). 
Menurut Haidar Bagir dan Zainal Abidin Bagir (1990: 34), meskipun Golshani adalah seorang professor fisika nuklir, namun sangat akrab dengan literatur-literatur klasik Islam berbahasa Arab, sehingga menjadi kelebihan dibandingkan dengan kebanyakan sarjana Muslim lain yang membahas persoalan relasi sains dan agama. Dengan latar keilmuan ini maka dalam berbagai karyanya Goslhani nampak sangat fokus dan fasih dalam membahas secara khusus tentang pandangan dunia Islam ilmu-ilmu kealaman, yang menurutnya, seringkali menjadi problem tersendiri di sebagian umat Muslim ketika merespon perihal sains dan agama. Sebagai fisikawan nuklir yang Muslim, Golshani merasa bertanggung jawab penuh secara intelektual, moral, dan spiritual, untuk berkontribusi terutama dalam menghadirkan dan mengelaborasi epistemologi Qurani sebagai fondasi dalam membangun apa yang disebutnya sebagai "sains Islami", yang juga meliputi ilmu-ilmu kealaman.

Dalam sejumlah tulisannya, menurut Syamsuddin, Golshani menyatakan bahwa yang dimaksud sains Islami adalah sains yang sesuai dengan pandangan dunia Islam. Bagi Golshani, pandangan dunia Islam tentang realitas yang harus menjadi praanggapan metafisik sains Islam adalah meliputi pandangan bahwa: pertama, alam diciptakan Tuhan dan Dia adalah Dzat Yang Memeliharanya; kedua, tidak membatasi realitas pada domain fisik-material saja; ketiga, menisbatkan tujuan pada alam semesta; dan, keempat, mengakui adanya tertib moral pada alam semesta. Keempat pandangan dunia ini dirumuskan Golshani dari kajiannya secara tematik terhadap ayat-ayat al-Quran. Prosedur yang ditempuh Golshani adalah dengan merujuk langsung pada ayat-ayat yang ia nilai berkaitan tentang pandangan dunia Islam tentang realitas. Kemudian ayat-ayat tersebut disusun dan racik agar menemukan rumusan Islam serta dilanjutkan dengan menguraikannya secara orisinal dengan memanfaatkan pandangan para filosof dan saintis Barat serta, tentu saja, pemikir Muslim sendiri (2012: 208).

Dalam kata pengantar bukunya, the Holy Quran and the Science of Nature, Golshani mengingatkan bahwa pembahasan dasar-dasar epistemologi dalam pandangan al-Quran untuk memperkuat kajian ilmuilmu kealaman merupakan hal yang masih sedikit dikerjakan dalam 
tradisi intelektual Islam dan ia menganjurkan agar para saintis Muslim untuk menyediakan lebih banyak lagi waktu dan energinya dalam berkontribusi pada persoalan yang amat penting ini. Melalui buku "Filsafat Sains Menurut al-Quran", Golshani berharap bisa merangsang penelitian-penelitian lebih lanjut dan sekaligus berkontribusi dalam membangkitkan semangat keilmuan umat Islam dan mengembangkan pengetahuan keilmuan di Dunia Islam (1990:36).

Golshani ingin mengingatkan kepada umat Islam bahwa salah satu ciri yang membedakan, dan sekaligus mengistimewakan, Islam dengan lainnya adalah penekanannya terhadap masalah ilmu (sains). Golshani mengajukan beberapa poin argumen, yaitu: pertama, al-Quran dan as-Sunnah mengajak kaum Muslim untuk mencari dan mendapatkan ilmu dan kearifan serta menempatkan orang-orang yang berpengetahuan pada derajat yang tinggi. Kedua, oleh sebab itu, al-Quran begitu banyak dan berulang menyebut kata al-ilm dan padanannya dalam berbagai ayat, yang menurut hitungannya, sejumlah 780 kali, tentu bukan jumlah yang pasti tidak bisa dikatakan sebagai jumlah yang sedikit. Ketiga, beberapa ayat pertama yang diwahyukan kepada Rasulullah SAW menyatakan tentang pentingnya membaca, pena, dan ajaran untuk manusia (Qs. Al-Alaq: 1-5); yang semua hal ini merupakan aktivitas dan media keilmuan. Keempat, perintah Allah SWT kepada malaikat untuk bersujud di hadapan Adam dikaitkan dengan keberhasilan Adam dalam proses penerimaan pengetahuan yang diajarkan oleh Allah, sebuah kemampuan yang diakui tidak dimiliki oleh para malaikat (QS. Al-Baqarah: 31-32). Kelima, keunggulan yang menjadi pembeda bagi orang-orang yang memiliki (ilmu) pengetahuan jika dibandingkan dengan yang tidak memilikinya (QS. Yasin: 9). Keenam, dorongan untuk berproses pembelajaran agar mendapatkan pemahaman keilmuan (QS. Al-Ankabut: 43). Ketujuh, (ilmu) pengetahuan yang dimiliki seseorang akan membimbingnya menjadi pribadi yang mampu merasa takut kepada Allah (sebagai bentuk pengakuan akan eksistensi-Nya sekaligus mentaati perintah dan kewajiban yang ditetapkan oleh-Nya). Kedelapan, beberapa hadits memuji ilmu dan mengapresiasi orang-orang berilmu, dan, kesembilan, bobot timbangan tinta (amal) saat Yaumul Hisab (Hari Perhitungan) bagi orang-orang 
berilmu lebih berat jika dibandingkan para Syuhada sekalipun (1990: 39-40).

Hal yang paling pertama dan menarik perhatian Golshani ketika mendiskusikan relasi Islam dan ilmu-ilmu kealaman adalah terlebih dahulu menjelaskan definisi pengetahuan ('ilm) dalam pandangan Islam. Problem definisi pengetahuan ('ilm), menurutnya, sudah muncul sejak periode awal Islam. Secara garis besar, terdapat dua arus utama yang berkembang, yaitu: pertama, beberapa sarjana yang mendefinisikan kata 'ilm secara spesifik hanya meliputi ilmu-ilmu keislaman saja. Arus kedua, adalah sebagian besar sarjana Muslim yang mendefinisikan istilah tersebut dalam pengertian umum dan mencakup spektrum sains yang luas, serta tidak membatasi pada ilmu keislaman. Dalam konteks ini Golshani cenderung menyepakati pandangan yang berkembang dalam arus kedua, yang mendefinisikan 'ilm secara luas dan meliputi baik ilmu-ilmu keislaman maupun ilmu-ilmu non keislaman. Baginya, kriteria bagi keterpujian suatu bidang ilmu dalam pandangan Islam adalah terletak pada kebergunaannya, yaitu apakah ilmu itu mampu membawa manusia kepada Tuhan atau tidak?. Oleh karena itu, bidang ilmu apa pun yang memiliki karakter tersebut adalah terpuji, sehingga usaha dan cara untuk memperolehnya merupakan suatu ibadah, kendati bukan berupa ilmu-ilmu yang bersifat keagamaan (2004:1).

Berdasarkan kajian epistemologisnya, Golshani menyimpulkan bahwa al-Quran menggunakan kata 'ilm atau pengetahuan baik untuk membahas ilmu-ilmu kealaman maupun ilmu-ilmu yang lain. Dengan demikian, ia menekankan, kajian tentang alam hendaknya direkomendasikan dengan tujuan untuk menemukan pola-pola Tuhan di alam semesta (ayat-ayat kauniyah) dan memanfaatkannya demi terwujudnya kemaslahatan umat manusia. Dalam pandangan dunia Islam, segala sesuatu di semesta ini bergerak di sekitar Tuhan, sehingga Tuhan adalah satu-satunya yang harus dipuji dan disembah, termasuk melalui jalan ilmu pengetahuan (sains). Hal-hal lain yang bersifat sekunder dan hanya layak dipuji sejauh membawa kita kepada Tuhan. Oleh sebab itu, pencarian kebenaran mutlak yang dimiliki Tuhan adalah tugas utama kita yang bisa dilakukan dengan menggunakan berbagai cara. 
Kajian tentang alam namun dengan tujuan demi mengungkap dan menemukan ayat-ayat Tuhan di semesta alam adalah sebentuk ibadah (2004: 4).

Al-Quran berulangkali menyatakan hal tersebut dalam berbagai ayatnya. Ada banyak pelajaran penting yang menurut Golshani (2004: 6) dapat kita serap dari al-Quran yang berkaitan dengan kajian tentang fenomena alam, yaitu tentang: asal-usul dan evolusi dunia (Qs. AlAnkabut: 20), adanya tata tertib (keteraturan) dan harmoni di alam semesta (QS. Al-Furqon:2), adanya tujuan di balik penciptaan alam semesta (QS. Al-Anbiya: 16), pentingnya kedudukan umat manusia (QS. Al-Isra: 70), adanya kebangkitan kembali (tumbuh kembang) dalam dinamika alam semesta (QS. Fathir: 9), dan argumen keesaan Tuhan dari kesatuan alam (QS. Al-Anbiya: 22). Baginya, prinsipprinsip al-Quran tentang realitas secara keseluruhan, seperti beberapa contoh ayat-ayat al-Quran tersebut, harus digunakan dan dipertegas untuk menggantikan pandangan dunia Barat yang selama menguasai pengembangan sains di dunia Muslim. Seperti halnya Naquib al-Attas, pencetus gagasan Islamisasi Ilmu. Golshani berkeyakinan bahwa wilayah paradigma adalah wilayah bersama di mana semua pandangan dunia dari latarbelakang manapun tentang realitas bisa masuk dan berkompetisi untuk saling mewarnai dan mendominasi, termasuk paradigma Qurani yang diyakininya bisa menggantikan dominasi paradigma positivisme dan emperisme dari sains Barat, semisal yang mempengaruhi teori evolusi Charles Darwin (Syamsuddin, 2012: 210).

Kesadaran epistemologis Qur'ani semacam inilah yang berusaha ditumbuh-kembangkan kembali oleh Golshani kepada umat Islam di era modernisasi yang berkarakter sekuler dalam pengembangan sains dan teknologi, di mana umat Islam pun tidak luput dari imbasnya. Apalagi diperparah dengan situasi internal umat Islam yang sebelumnya selama berabad-abad tertidur dan stagnan dalam pengembangan khazanah intelektualnya akibat pandangan dikotomis yang membedakan sains keislaman dan sains umum, dengan penyingkiran eksistensi sains umum dari altar intelektualitas Islam. Akibatnya, umat Islam di abad modern hanya menjadi konsumen dan subordinasi dari kemajuan sains dan teknologi yang dihasilkan peradaban Barat. 
Di sini lah Golshani ingin turut serta "membangunkan" kesadaran kolektif umat Islam dalam pengembangan sains dan teknologi demi terwujudnya peradaban yang baik dan maju di dunia Islam. Golshani ingin mengajak untuk secara serius mengembangkan capaian sains di kalangan umat Islam dan tidak mengabaikan bidang ilmu kealaman dalam konstruk keilmuan Islam. Yang penting untuk diperhatikan adalah hanya soal bagaimana motivasi dalam kajian ilmu-ilmu kealaman tersebut dilakukan tetap dengan koridor menemukan ayat-ayat Tuhan dalam semesta alam. Motivasi seperti inilah yang menurut Golshani sangat dominan dan menampak di kalangan sarjana Muslim pada zaman keemasan peradaban Islam. Dalam pandangan mereka, upaya pencarian ilmu-ilmu kealaman dan ilmu-ilmu matematis adalah untuk mengetahui ayat-ayat Tuhan di alam semesta. Sebab, tiap-tiap bidang ilmu tersebut menunjukkan satu dimensi ciptaan Tuhan dan memiliki kesatuan organis. Ilmuan muslim terdahulu tidak memisahkan kajian tentang alam dari pandangan dunia mereka yang religius dan mencari kerja inklusif yang memungkinkan mereka menjelaskan keseluruhan alams semesta. Bagi mereka, berdasarkan pandangan dunia yang mereka gali dari al-Quran dan as-Sunnah, kajian tentang alam mencakup baik unsur-unsur fisika maupun metafisika serta semua bidang ilmu pengetahuan dipandang sebagai cabang-cabang dari pohon tunggal yang akarnya adalah metafisika Islam. Dengan demikian, semua bidang ilmu pada dasarnya adalah penting, di mana sebagian dari ilmu pengetahuan berupa ilmu yang diwahyukan dan sebagian lainnya, diperoleh melalui eksperimentasi, observasi, penalaran teoritis, dan intuisi (2004:3-4).

Dalam diskursusnya, menurut Kuswanjono, Golshani menggunakan istilah ilmu sakral (sacred sciences) dan ilmu sekuler (secular sciences). Golshani menjelaskan bahwa ilmu sakral adalah ilmu yang terbingkai dalam pandangan dunia teistik; yang memandang Tuhan sebagai Pencipta dan Pemelihara semesta dan tidak membatasi wujud hanya dalam wilayah material, sembari meyakini pada tujuan bagi alam ciptaan dan mengakui aturan moral yang ditetapkan-Nya. Sementara ilmu sekuler adalah ilmu yang dibangun dengan paradigma yang sama sekali mengabaikan semua hal yang dipedomani 
ilmu sakral tersebut (2010: 55). Mehdi Golshani, menurut Samsul Hidayat (2014: 91), dalam makalah Science and The Sacred: Sacred Science vs. Secular Science, berusaha menguraikan sejumlah pokok masalah menyangkut sains sakral dan sains sekuler dengan pernyataan bahwa sains sakral adalah sains yang terbingkai dalam pandangan dunia yang teistik; pandangan dunia yang menganggap Tuhan sebagai Maha Pencipta dan Maha Pemelihara alam semesta, yang tidak mengurung wujud dalam wilayah material, meyakini pada tujuan bagi alam penciptaan dan mengakui aturan moral. Sementara, sains sekuler bersifat mengabaikan berbagai hal tersebut.

Golshani kemudian mendeskripsikan beberapa perbedaan pandangan antara sains sakral dan sains sekuler dalam sejumlah poin, yaitu; pertama, cara pandang terhadap alam fisik sebagai satu-satunya yang ada atau sesuatu yang diciptakan; kedua, spesialisasi yang berbuntut pada fragmentasi sains atau mencari kesatuan yang mendasari tatanan penciptaan; ketiga, mengabaikan/menolak ide adanya tujuan (teleologi) bagi alam atau menerimanya; keempat, mengembangkan kenetralan pada nilai atau mengintegrasikan pengetahuan dengan serangkaian nilai; kelima, sains digunakan untuk mengendalikan dan memanipulasi alam dan masyarakat atau dipakai untuk mendapatkan kebijaksanaan dan memecahkan masalah-masalah individu/masyarakat; dan, keenam, bungkam terhadap makna dan tujuan kehidupan manusia dan tentang moralitas atau tidak mengungkung realitas pada wilayah empiris dan bekerja pada kerangka metafisis yang lebih mencakup, dimana tingkat-tingkat realitas lebih tinggi diakui (Hidayat, 2014: 92).

Menurut Hidayat (2014: 92), dalam buku The Holy Qur' an and The Science of Nature (1984), Golshani mengibaratkan sains ibarat pohon yang dahannya kering, sehingga agar pohon tersebut tumbuh dan berkembang secara subur, maka ia harus 'disiram' dengan agama. Golshani beralasan karena sains tidak bebas nilai dan keyakinan bahwa sains modern bersifat netral, bebas nilai, objektif dan sebagainya merupakan produk kejahilan belaka. Dengan demikian, masih terbuka lebar bagi kaum Muslim untuk menggugat absolutisme sains modern, dengan mengupayakan sains alternatif yang lebih menjamin peradab- 
an yang sesuai dengan tuntutan kemanusiaan, termasuk dengan sains Islam. Di sinilah relevansi mengajukan nilai-nilai Islam dalam membangun sains Islam, sebagai sains alternatif, walaupun sains Islam tidak berurusan dengan produktivitas sains itu sendiri seperti eksperimentasi dan teoretisasi. Nilai agama tidak cukup diwujudkan dalam etika sains, namun konsep ontologis (sebagai objek sains) dan epistemologisnya (sebagai metode keilmuan) juga harus melibatkan nilai-nilai Islam (konsep aksilogis).

Golshani menyarankan nilai-nilai Islam tersebut perlu dirumuskan berdasarkan pandangan dunia al-Quran. Meskipun dalam hal ini kita tidak perlu mendudukan al-Quran sebagai sebuah buku sains secara teknis, sebab al-Quran sesungguhnya memang merupakan kitab petunjuk. Rujukan al-Qur'an tentang fenomena alam hanya untuk mendekatkan manusia pada Allah dengan cara merenungkan wujud alam. Dalam perpektif al-Qur'an, memahami alam bukanlah usaha yang bermakna kecuali bertujuan memahami Allah dan mendekatkan diri pada-Nya. Karena itu, kesimpulan ilmiah ilmuwan beragama akan berlainan dengan ilmuwan ateis, walaupun menggunakan pendekatan teori yang sama. Bagi ilmuwan yang percaya kepada Tuhan, studi eksperimental tak bisa memberikan pengetahuan final. Pada akhirnya, manusia juga memiliki keterbatasan. Karena itu penalaran ilmiah harus dibarengi dengan perenungan yang tak terikat dengan pengetahuan indrawi (Hidayat, 2014: 93).

Masih menurut Hidayat (2014: 93), gagasan tentang sains sakral dikembangkan Golshani menjadi apa yang disebut sebagai "sains Islam". Dalam buku Issues in Islam and Science (2004) Golshani berupaya memaparkan pikiran-pikirannya untuk menjelaskan gagasan sains Islam tersebut. Di buku ini Golshani membantah secara tegas terhadap pandangan bahwa sains adalah bebas dari nilai dan ideologi. Baginya, semua teori sains, khususnya teori-teori fundamental, melibatkan praanggapan-praanggapan metafisika yang berakar pada world view para saintis bersangkutan. Golshani mendefinisikan "sains Islam" sebagai jenis sains yang di dalamnya pengetahuan tentang dunia fisik terkandung dalam pandangan dunia Islam. Pemahaman yang keliru tentang makna sains Islam karena sebagian pihak memahaminya sebagai sains 
yang melibatkan pembahasan tentang apa yang disebut sebagai mukjizat ilmiah al-Qur'an, atau sains yang membahas tentang cara-cara yang mungkin untuk membuktikan adanya Tuhan, atau kegiatan ilmiah harus dilakukan dengan cara baru yang khas "Islami", atau sains yang mencoba menisbatkan asal-usul sains kepada para sarjana muslim, atau bahwa untuk penelitian fisika-kimia, orang harus merujuk pada al-Qur'an dan Sunnah dan secara eksklusif berpaling pada teori-teori dan eksperimen ilmiah lama. Pemahaman yang reduksionis atau cenderung menyederhanakan permasalahan tersebut menurut Golshani jelas sangat tidak relevan dengan makna sains Islam yang ingin mendasarkan penemuan sains pada sebuah eksperimen yang bergantung pada pengandaian-pengandaian (presuppositions) metafisika baik yang eksplisit maupun implisit. Apa yang dimaksudkan sebagai sains Islami adalah sains yang berkerangka world view Islam, dimana ciri-cirinya dapat dilihat pada bagaimana posisi eksistensi pencipta tetap terjaga, tidak membatasi alam semesta hanya pada ranah materi saja (materialis), atau ruang saja (parmenides), atau data indra saja (positivis), atau sebatas angka-angka saja (pythagorean). Di samping itu tujuan tetap dinisbatkan pada alam semesta, serta menerima tertib moral bagi alam semesta.

Golshani berpandangan bahwa sains tidak bisa dipisahkan dari seperangkat nilai yang mengitarinya. Walaupun sains merupakan fakta saintifik yang berakar pada realitas obyektif, dan memiliki metode universal yang khas, terdiri dari eksperimen, observasi dan kerja teoretis, kerja saintifik sangat sarat dengan praduga-praduga filosofis dan keagamaan. Sementara metafisika memainkan peran penting pada segenap tahapan aktivitas saintifik, meskipun bisa saja semua itu berlangsung tanpa disadari. Biasanya praduga-praduga metafisika terjadi pada saat aktifitas saintik dilakukan, terutama pada saat penalaran teoritis dan penafsiran data (selain pengumpulan dan penyusunan fakta). Pada titik ini, seorang teistik melihat pada fakta dan mengasimilasikannya dalam konteks teistik, sementara seorang ateis akan menafsirkan fakta dengan mengikuti kecenderungan ateistiknya (Hidayat, 2014: 97). 


\section{RELEVANSI DALAM PENGEMBANGAN KEILMUAN AGAMA DAN SAINS}

Sains dan agama adalah dua entitas yang berbeda sebagai sumber pengetahuan dan sumber nilai bagi kehidupan manusia. Meskipun secara filosofis keduanya berbeda namun secara historis pernah dilakukan upaya-upaya konsolidatif baik dalam konteks kontraproduktif maupun dalam konteks mutualistik (Arifin, 2008: 173). Langkah konsolidatif ini, disimpulkan dalam riset Zainul Arifin, dilakukan supaya di antara keduanya tidak menjadi instrumen dan media perseteruan dan sumber konflik bagi kehidupan manusia, namun sebaliknya, keduanya semestinya menjadi sumber inspirasi meningkatkan kearifan dan kesadaran dinamis diri manusia dalam hubungannya dengan alam, secara makrokosmik, dan dengan sesama manusia secara mikrokosmik, serta dengan Tuhan secara transendental. Oleh sebab itu, agama dan sains perlu meniscayakan diri untuk sama-sama mengabdi untuk kepentingan kesejahteraan dan kemakmuran manusia (2008: 174).

Sebagaimana agamawan, menurut Hidayatullah (2015: 38), para saintis memiliki langkah kerja yang khas, dengan menggunakan berbagai tata cara yang bersifat ilmiah dalam melakukan kegiatannya, dengan tata cara yang berpola atau keteraturan tertentu. Pola kerja ilmiah bisa saja berupa pelukisan, pengamanan, penggolongan, pengukuran, penguraian, penyelidikan, percobaan, dan perbandingan. Tata cara ilmiah terdiri dari serangkaian tata langkah yang tertib, yang pada umumnya berupa: penentuan masalah, perumusan patokan duga (hipotesis), pengumpulan bahan keterangan, penurunan kesimpulan, dan pengujian hasil. Pelaksanaan pola-pola dari tata cara ilmiah biasanya memerlukan rincian lebih lanjut berupa aneka tata kerja seperti misalnya melakukan pemanasan atau pembekuan, wawancara, dan mengerjakan perhitungan, dengan menggunakan alat-alat bantu tertentu hingga terhimpunnya kumpulan pengetahuan yang teratur.

Metode ilmiah digunakan oleh para saintis dengan memiliki suatu cara tertentu dalam memperoleh pengetahuan tentang gejala alam. Metode ini mensyaratkan pengamatan sistematis atas gejala yang dipe- 
lajari dan mencatat pengamatan-pengamatan ini sebagai bukti, atau data ilmiah. Para saintis berupaya mengaitkan data yang ada dengan cara yang koheren, bebas dari kontradiksi internal. Metode ilmiah digunakan untuk memproduksi teori ilmiah, setelah mengalami proses pengujian dan pengamatan lebih lanjut, dan jika mungkin, eksperiman tambahan, dan bahkan mampu memprediksi hasil-hasil eksperimen baru. Sains dengan metode ilmiahnya, kendati demikian, jika diperbandingkan dengan metode yang dikandung agama, maka ada sejumlah hal yang bisa disimpulkan, yaitu: pertama, adanya kemiripan agama dan sains yang berisi tentang: pengalaman dan interpretasi, peran komunitas dan analogi dan model. Hal kedua adalah menyangkut tentang partisipasi individu dan iman religius yang mencakup pembahasan partisipasi individu dan konsentrasi puncak, teologi biblikal dan teologi natural, interaksi Iman (komitmen) dan akal (penemuan) yang sama-sama tidak eksklusif, dan komitmen religius dan pertanyaan reflektif. Ketiga, adalah berkaitan dengan persoalan wahyu dan keunikan yang menyangkut ketergantungan agama samawi terhadap peristiwa historis khususnya perbandingan tentang hubungan partikularitas dan universilitas menurut teolog, ilmuwan dan sejarawan (Gie, 2003: 23; Hidayatullah, 2015:39).

Sampai saat ini, menurut Hidayat, wacana tentang hubungan sains dan agama terus mencari bentuk interaksinya yang tepat. Banyak tawaran alternatif yang telah dimunculkan dan disodorkan kepada kita, termasuk dari kalangan saintis dan teolog Muslim. Namun demikian, jika tidak cermat, terkecuali bagi yang mendukungnya, maka wacana tersebut akan terjebak dalam pembenaran ala Harun Yahya dan Maurice Bucaille (Bucailliyan); yang cenderung mencari pembenaran atas teori ilmiah, contohnya Teori Dentuman Besar, dengan menyebutkan bahwa itu ada dalam kitab suci al-Qur'an. Inilah yang coba dihindari, antara lain oleh Bruno Guiderdoni, Direktur Riset Institut Astrofisika Paris, dan Mehdi Golshani. Dengan memiliki kesamaan epistemologi, yaitu sebagai proses pencarian kebenaran yang terbuka, sains dan agama seharusnya tidak mengalami konflik yang berkepanjangan. Sebagaimana pendapat yang umum dipahami, sains berkaitan dengan "fakta", sementara agama berkaitan dengan "makna", atau 
sains berupaya menjawab "bagaimana" dan agama "mengapa", artinya sains dan agama telah memiliki ranah dan wilayah yang berbeda tapi saling mengisi. Namun menurut Bruno Guiderdoni, persoalannya adalah memang benar bahwa sains berkaitan dengan sebab-sebab efisien dan agama dengan sebab-sebab final, tapi arus umum dalam perkembangan sains adalah bahwa sebab-sebab efisien sering menyisihkan sebab-sebab final dan akhirnya melenyapkannya (2014: 90).

Dengan pemahaman yang holistik tentang cara alam dan cara Tuhan bekerja, maka kehadiran agama atau Tuhan dalam sains seharusnya tidak perlu diingkari, apalagi ditakuti. Apa yang dikatakan Keith Ward dalam bukunya God, Chance and Necessity, bahwa "God is beginning to argue back", merupakan tanda bahwa hubungan antara agama dan sains sesungguhnya dapat didekatkan dengan cara-cara yang lebih konstruktif dan seimbang jika keduanya masih sepakat untuk menemukan hakikat eksistensi dan problem jagad raya dalam sebuah tanggung jawab yang sama. Tanpa mengabaikan persoalan internal yang dihadapi baik oleh sains maupun agama, keduanya masih memiliki tanggung jawab kolektif yang patut dicarikan penyelesaiannya secara bijak dan akurat. Persoalan yang dihadapi seperti bencana yang terjadi pada masa kini dan mendatang: kemiskinan penduduk, perubahan iklim, erosi dan kekeringan, penebangan hutan, limbah, ketimpangan kekayaan, kriminalitas, degradasi moral, dan masalah-masalah lainnya menuntut jawaban dan solusi yang tepat dalam rangka mengejawantahkan peran sains dan agama sebagai pro kelestarian alam dan kemanusiaan. Bumi dan seisinya masih membutuhkan tangan-tangan sains dan agama guna memberikan rasa aman bagi semesta sehingga kesinambungan dan keselarasan dapat terjalin dan tertata, sampai semua akhirnya menyadari bahwa alam semesta dan seisinya adalah Hadiah Terindah dari Sang Pencipta. (Hidayat, 2014: 99).

Untuk mewujudkan harapan-harapan ideal dalam relasi sains dan agama serta kemanfaatannya bagi kemaslahatan umat manusia dan keselarasan alam semesta tersebut, maka percikan pemikiran Golshani beserta tawaran-tawaran instrumentatifnya, terutama dengan 
upaya-upaya pengembangan bidang-bidang ilmu kealaman di kalangan umat Islam merupakan sesuatu yang sangat penting dan patut dipertimbangkan. Golshani, melalui sejumlah tulisannya, terutama dalam dua buku magnum opus-nya tentang relasi sains dan agama, yaitu buku The Holy Qur'an and The Science of Nature (1984) dan buku Issues in Islam and Science (2004), banyak menawarkan wacana tentang agama dan sains yang konstruktif, bersifat terbuka, namun tanpa kehilangan sikap kritis. Meskipun belum semua persoalan terkait relasi sains dan agama terjawab olehnya, namun menurut Zaenal Abidin Bagir (2004: xii), Golshani termasuk pemikir yang mampu menawarkan jawaban yang konstruktif. Hal ini karena kredibilitas dan otoritas Golshani dalam persoalan ini tidak diragukan sebagai seorang fisikawan yang aktif, terutama dalam riset seputar kosmologi dan mekanika kuantum. Golshani juga pengkaji filsafat Sains yang sangat serius, terbukti dengan upayanya sebagai pendiri dan direktur jurusan filsafat di universitasnya. Satu lagi yang memprkuat kredibilitasnya adalah bahwa Golshani cukup akrab dengan tradisi intelektual agamanya dan tampak tak tergoda untuk terjebak dalam kecenderungan-kecenderungan superfisial oleh sejumlah kelompok dan sarjana Muslim lainnya ketika membahas relasi sains dan agama.

\section{SIMPULAN}

Mehdi Golshani, sebagai fisakawan nuklir yang memiliki pijakan yang kuat terhadap tradisi intelektual agamanya, Islam, sangat mendorong para saintis Muslim untuk menyediakan lebih banyak lagi waktu dan energinya dalam berkontribusi pada pembahasan dasardasar epistemologi dalam pandangan al-Quran untuk memperkuat kajian ilmu-ilmu kealaman. Golshani sesungguhnya tidak sekadar menganjurkan dan memberi dorongan, namun ia betul-betul memberikan contoh konkrit keseriusannya dalam soal ini. Melalui berbagai karya tulisnya, Golshani berharap bisa merangsang penelitian-penelitian lebih lanjut dan sekaligus berkontribusi dalam membangkitkan semangat keilmuan umat Islam dan mengembangkan pengetahuan keilmuan di Dunia Islam. 
Golshani adalah figur intelektual Muslim yang mewakili pandangan yang mendefinisikan 'ilm secara luas dan meliputi baik ilmuilmu keislaman maupun ilmu-ilmu non keislaman. Baginya, kriteria bagi keterpujian suatu bidang ilmu dalam pandangan Islam adalah terletak pada kebergunaannya utuk membawa manusia kepada Tuhan. Oleh sebab itu, Golshani sangat yakin bahwa melalui pengembangan ilmu-ilmu kealaman, tanpa mengecualikan ilmu-ilmu keislaman, juga pada akhirnya akan dapat membawa manusia menemukan Tuhannya, dengan catatan ia mendapat bekal dan dasar yang cukup dari fondasi metafisika leilmuannya. Di sinilah yang ingin dikontribusikan Golshani, sekaligus membuktikannya, bahwa al-Quran menyediakan perangkat nilai-nilai yang dapat digunakan para saintis, termasuk untuk mengembangkan bidang-bidang ilmu kealaman. Baginya, kesadaran epistemologis Qur'ani merupakan keniscayaan bagi umat Islam yang di era modernisasi tengah berhadapan dan mengonsumsi pengembangan sains dan teknologi Barat yang berkarakter sekuler. Oleh sebab itu, Golshani menyerukan ajakan untuk secara serius mengembangkan capaian sains di kalangan umat Islam dan agar tidak lagi mengabaikan bidang ilmu kealaman dalam konstruk keilmuan Islam.

Dalam kaitan ini, Golshani terlebih dulu mengelaborasi dua istilah teknis, yaitu: ilmu sakral (sacred sciences) dan ilmu sekuler (secular sciences). Dari istilah ilmu sakral inilah kemudian ia memperkenalkan sebuah paradigma ilmu yang ia sebut sebagai sains Islam. Sains Islam, oleh Golshani, dibangun berdasarkan nilai-nilai Islam yang dirumuskan berdasarkan pandangan dunia al-Quran. Gagasan sains Islam Golshani adalah sebuah kontribusi nyata dan konstruktif dalam mewujudkan harapan-harapan ideal dalam relasi sains dan agama serta kemanfaatannya bagi kemaslahatan umat manusia dan keselarasan alam semesta, terlebih upaya-upaya pengembangan bidang-bidang ilmu kealaman di kalangan umat Islam di tengah dominasi peradaban Barat yang sekuler. 


\section{DAFTAR PUSTAKA}

Arifin, Zainul, 2008. " Model-Model Relasi Agama dan Sains", PsikoIslamika vol. 5 no2 , 2008, Fakultas Psikologi UIN Malang: 174), diunduh pada 26 Mei 2016, pkl. 16.00, dari http://id. portalgaruda.org/?ref=search\&mod=document\&select=titl e\&q=relasi+agama + dan+sains\&button=Search+Document

Bagir, Zainal Abidin, 2002, "Pergolakan Pemikiran di Bidang Ilmu Pengetahuan", dalam Taufik Abdullah, dkk. (ed.), Ensiklopedi Tematis Dunia Islam Dinamika Masa Kini, PT. Ichtiar Baru Van Hoeve, Jakarta, hal. 137-159.

2004, "Kata Pengantar Zainal Abidin Bagir", dalam Mehdi Golshani, Melacak Jejak Tuhan Dalam Sains Tafsir Islami Atas Sains, terj. Ahsin Muhammad, CRCS UGM dan Penerbit Mizan, Bandung, hal. xi-xxiii.

2006, “Agama dan Sains-Agama: Perbandingan Beberapa Tipologi Mutakhir", dalam Zainal Abidin Bagir, Lik Wilardjo, Arqom Kuswanjono, dan Muhammad Yusuf (eds.), Ilmu, Etika, dan Agama, Menyingkap Tabir Alam dan Manusia, CRCS UGM, Yogyakarta, hal. 3-18.

Haidar Bagir dan Zainal Abidin Bagir, 1990. “Filsafat Sains Islami: Kenyataan atau Khayalan?", dalam Mehdi Golshani, Filsafat Sains Menurut al-Quran, Cetakan ke-3, Penerbit Mizan, Bandung.

Billa, Mutamakkin, 2011. "Pemaknaan Teologis M. Fethullah Gulen tentang Relasi Agama dan Sains", Teosofi, Jurnal Tasawuf dan Pemikiran Islam, Volume 1 Nomor 2 2011. Fakultas Ushuluddin IAIN Sunan Ampel, Surabaya.

Daya, Burahanuddin. 1993, "Dakwah, Misi, Zending, dan Dialog Antar Agama Di Indonesia", dalam Abdurrahman, dkk (ed.), Agama dan Masyarakat, IAIN Sunan Kalijaga Press, Yogyakarta.

Gie, The liang.2003, Sejarah Ilmu-Ilmu, PUBIB dan Sabda Persada, Yogyakarta.

Golshani, Mehdi, 1990, Filsafat Sains Menurut al-Quran, Cetakan ke-3, Penerbit Mizan, Bandung. 
2004, Melacak Jejak Tuhan Dalam Sains: Tafsir Islami Atas Sains, Penerbit Mizan, Bandung.

Hidayat, Samsul. 1014, "Sacred Science vs. Secular Science: Carut Marut Hubungan Agama dan Sains", Kalam: Jurnal Studi Agama dan Pemikiran Islam Vol. 8, No. 1, Juni2014, hal.87-101.

Hidayatullah, Syarif. 2015. "Sains dan Agama: Suatu Telaah Relasi dan Metodologi", (Laporan Akhir Penelitian), Fakultas Filsafat UGM, Yogyakarta.

Iqbal, Sir Muhammad.2016, Rekonstruksi Pemikiran Religius dalam Islam, terj. Hawasi dan Musa Kazhim, PT. Mizan Pustaka, Bandung.

Kaelan, 2005. Metode Penelitian Kualitatif Bidang Filsafat, Paradigma, Yogyakarta.

Koeswanjono, Arqom. 2010, Integrasi Ilmu dan Agama Perspektif Filsafat Mulla Sadra, Badan Penerbit Filsafat UGM, Yogyakarta.

Leahy, Louis. 2006, "Agama dan sains dalam Perdebatan", dalam Zainal Abidin Bagir, Lik Wilardjo, Arqom Kuswanjono, dan Muhammad Yusuf (eds.), Ilmu, Etika, Dan Agama, Menyingkap Tabir Alam dan Manusia, CRCS UGM, Yogyakarta, hal. 1933.

Lechte, John. 2001, 50 Filsuf Kontemporer Dari Strukturalisme Sampai Posmodernisme, terj. A. Gunawan Admiranto, Penerbit Kanisius, Yogyakarta.

Menzies, Allan, 2014: Sejarah Agama-Agama: Studi Sejarah, Karakteristik dan Praktek Agama-Agama Besar di Dunia, terj. Dion Yulianto dan EmIrfan, FORUM, Yogyakarta.

Moleong, Lexy J. 1995, Metodologi Penelitian Kualitatif, PT. Remaja Rosdakarya, Bandung.

Ravertzs, Jerome R., 2014, Filsafat Ilmu Sejarah dan Ruang Lingkup Bahasan, terj. Saut Pasaribu, Cetakan ke-5, Pustaka Pelajar, Yogyakarta.

Safi, Louay. 2001, Ancangan Metodologi Alternatif (The Foundation of knowledge: a comparative study in Islam and Western method of inquiry), terj. Imam Khoiri, Tiara Wacana, Yogyakarta. 
90 Jurnal Filsafat, Vol. 27, No. 1, Februari 2017

Syamsuddin, Ach. Maimun.2012, Integrasi Multidimensi Agama E Sains: Analisis Sains Islam Al-Attas dan Mehdi Golshani, IRCiSoD, Yogyakarta.

Soetomo,Greg. 1995, Sains dan Problem Ketuhanan, Penerbit Kanisius, Yogyakarta. 